\title{
Learning Style of Generation Z Students in Japanese and Korean Languages Vocabulary Learning in Vocational College of UGM
}

\author{
Mery Kharismawati, S.S., M.Si ${ }^{1}$, Ummul Hasanah, S.S., M.A ${ }^{2}$ \\ (mery.kharismawati@ugm.ac.id ${ }^{1}$,ummul.hasanah@ugm.ac.id ${ }^{2}$ \\ ${ }^{1,2}$ Gadjah Mada University, Yogyakarta, Indonesia
}

\begin{abstract}
Vocational College of Universitas Gadjah Mada has Japanese and Korean majors. In learning these two languages, one of the keys to being proficient in mastering them is by enriching vocabulary. This study aims to reveal the learning style of the $\mathrm{Z}$ generation students, namely the 2018 class of students majoring in Japanese and Korean. By using the questionnaire method, and observation, it can be seen that Japanese and Korean students like the visual learning style and the mixture of visual, auditory and kinesthetic. But some students have not yet found their learning style. From the level of satisfaction of achieving individual scores, the learning style possessed by students considered not to be effective enough by a user. Students still find difficulties in arranging sentences and this is a consequence of the lack of vocabulary. In the future, vocabulary learning methods are needed by the character of the learning style of the students. This measure is to increase vocabulary mastery that supports achievement both in academic grades and for language skill tests such as JLPT and TOPIK.
\end{abstract}

Keywords: vocabulary learning Style, Japanese language, Korean language, Z generations

\section{INTRODUCTION}

Due to the booming of Japanese and Korean pop culture in Indonesia, young generations are interested in Japanese and Korean language and they want to stay close to those customs. According to the survey held by The Japan Foundation [1], the number of Japanese language learners in Indonesia is in the second position after China; the number is dominated by high school students. It goes the same with the Korean language that is taking interest due to the booming of K-pop, Korean drama, and Hallyu (Korean Wave) in Indonesia. Besides the culture, Korean language learners are increasing because South Korea has made many cooperations with Indonesia. The Korean government has promised the ease of immigration process for a visitor coming to South Korea [2].

In Vocational College UGM (SV UGM), there is a Diploma III Program for the Korean language and Diploma III Program for the Japanese language. The challenge of Japanese and 
Korean teachers is about how to handle the students in the category of $\mathrm{Z}$ generation. Pratama [3] gives an understanding of the term $\mathrm{Z}$ generation, which is known as the digital generation who grows and develops with the dependency of digital technology. Z generation is born in a modern world, so it is easier for them to know and understand technology. They also like audiovisual format, depending on technology, easy to understand real example, critical in delivering an idea, can learn better with the teacher who acts as friend dan like to innovate [4].

Japanese and Korean language learning is different from English language learning which has already been familiar in daily life. Mastering vocabulary is essential to be fluently communicated in these two languages. Hence, learners of these two languages need a suitable strategy to master vocabulary. This research would observe the learning style of Korean and Japanese Departement students in the class of 2018 which later can be the foundation for the teacher to develop teaching method and suggest the most suitable vocabularies learning strategy to improve the skills of Korean and Japanese language study program di SV UGM.

\section{METHOD}

The approach that is used in this research is quantitative. Research objects used are the students of 2018 in the Korean and Japanese language study program total of 46 students. (Japanese language study program students are 20 dan Korean language study program students are 26). The data is collected using the observation method to the vocabulary learning done by the class of 2018. A closed questionnaire was given to the students and then analyzed by using descriptive presentative analysis. The questionnaire is used to understand the learning style of the respondents which can be linked to the learning strategy that should be done to improve the vocabulary learning skills.

\section{RESULT AND DISCUSSION}

\subsection{The Characteristics of Japanese dan Korean Language}

\section{a. Japanese Language}

Characteristic of the Japanese language is divided into hatsuon, moji goi, bunpo, dan hyogen, which means pronunciation, vocabularies, grammar, and expression. Japanese language pronunciation is easy to follow because similar to Indonesian language; it has vocal sound A, I, U, E, O. There is no single consonant other than ' $n$ ', and one thing to be paid attention is the long and short word pronunciation and the omission of vocal letter at the end of word 'desu'. The Japanese language has three kinds of letter style; they are hiragana, katakana, kanji, beside the alphabet letter/romaji. To learn the Japanese language, the learners must familiarize themselves with those kinds of writing styles and understand that the predicate in the Japanese language sentence is put at the back of the sentence. Meanwhile, in the Indonesian language, the common pattern of a sentence is Subject-Predicate-ObjectAdverb; in the Japanese language, the pattern will be Subject-Object-Predicate.

Each foreign language learner needs to enrich the vocabulary to be able to communicate in that language fluently. Word is the smallest grammatical element, which derives from the world-class nomina, pronomina, and numerals. It has the function of subject, predicate, and adverb. Etymologically, the kind of word that may function as grammatical is Japanese vocabularies, kanji, borrowed word, and mixed vocabularies [5]. The importance of learning Japanese language vocabulary can be seen clearly from the ability of a learner in passing the 
test of Japanese language (Japanese Language Proficiency Test) which has the minimum requirement of vocabularies at each level.

To pass the JLPT test which now has become the standard of Japanese language proficiency to enter the working field, a learner must understand the meaning, how to read, and the writing shape of a word. Here are the requirement of minimal words to pass JLPT in each level:

Table 1. Number of vocabularies to pass JLPT

\begin{tabular}{lll}
\hline Level & Vocabularies & Kanji \\
\hline N5 & 800 & 100 \\
\hline N4 & 1500 & 300 \\
\hline N3 & 3700 & 650 \\
\hline N2 & 6000 & 1000 \\
\hline N1 & 10.000 & 2000 \\
\hline
\end{tabular}

Source: https://kawakawalearningstudio.com/all/roadmap-for-the-jlpt/

Minimum standard of Japanese language ability asked by the working field is in N3 level, so the learner must master vocabularies and kanji as seen from the table above,

\section{b. Korean Language}

Similar to the Japanese language, the Korean language also requires its learner to learn a unique letter from Korea; it is called hangeul. The sentence pattern is the same as the Japanese language which places predicate at the back of a sentence. The Korean language has various kinds of marker particles. Word function in a sentence is determined by the marker particles put on that word. Word order in Korean sentences is flexible, but the function of the subject, object, as well as adverb will not change the position and its meaning.

To measure Korean language ability, there is a test called TOPIK (Test of Proficiency in Korean). This test is managed by NIIED(National Institute for International Education) since 1997. TOPIK test is divided into two parts; they are TOPIK 1 for beginner level and TOPIK 2 for intermediate and advanced level. To pass TOPIK, a Korean language learner must master the vocabularies commonly used in the Korean language, it is $1200-1500$ words for TOPIK 1 and 6000 words for TOPIK 2 [6].

\subsection{Vocabularies Learning Condition in Japanese and Korean Language Class of 2018}

In language learning, mastering vocabularies hold a crucial role. David Wikis in Thornbury (2002) in Alqahtani [7] stated that,

"Without grammar very little can be conveyed, without vocabulary nothing can be conveyed,"

Alqahtani [7] emphasized that Laufer and Nation (1999), Maximo (2000), Read (2000), Gu (2003), Marion (2008) and Nation (2011) understood that vocabularies learning is essential to master a second language, and has a vital role in completing communication aspect either for spoken or written.

Vocabularies learning in Japanese language study program year of 2018 is given an integrated class called basic Japanese language class, it consists of Japanese language for communication, listening, the practice of Japanese language for communication, and practice 
of Japanese language listening. Vocabularies are used repeatedly in those classes. In the curriculum of 2007 which is used in the year 2018, the materials in semester 1 and semester 2 are designed to make students pass JLPT level N4. Meanwhile, 3 years period of study is designed to prepare students to pass the Japanese language test JLPT minimum level of N3. Japanese language students have a vocabulary compilation book and it is hoped that students can study independently besides using the book which is typically used in the class so they can learn more on vocabularies that commonly appear in JLPT questions. Every other week, there is a test to check students' understanding of the material given and at the end of the semester, there is a final exam.

Studying in the Korean language study program, students need to master the aspect of reading, writing, listening, and speaking. Vocabularies learning is included in those aspects because it is considered that students cannot make proper sentences if they do not understand the new vocabularies being taught in class. Korean language study program teaches new vocabulary to the students at the beginning of every chapter in the Korean book given. For example, in chapter 1 there is a chapter about visiting a friend, then vocabularies in that chapter will be explained one by one. In each class, the teacher will explain the new word and how to use the word correctly. Besides that, the students are also required to add up the new vocabularies actively by watching Korean Drama or listening to Korean songs. Every other week there is a test to check their understanding of the materials given in class. The test includes grammar, reading, and writing skills assessment. In reading or grammar, there will be a list of new vocabularies; then students need to translate the vocabularies either to Korean or Indonesian language. Hence, students need to memorize and learn how to use the new vocabulary in each chapter.

With those vocabularies learning conditions in classes, $\mathrm{Z}$ generation students year of 2018 with their learning style, following classes, and take the exam that needs an abundance of vocabularies learned for two semesters. Here is the list of the final score for Basic Japanese Language II and General Korean Language, these two classes are considered representative to the understanding of vocabularies learned by students in semester 1 and 2 for Japanese and Korean Language learning.

Table 2.

List of Final Exam Score of Basic Japanese Language II Even Semester Academic Year 2018/2019 Class of 2018 Japanese Language Study Program SV UGM

\begin{tabular}{lll}
\hline No & Respondent & Final Score \\
\hline 1 & FR & 73 \\
\hline 2 & DP & 55 \\
\hline 3 & MD & 70 \\
\hline 4 & PN & 80 \\
\hline 5 & DK & 71 \\
\hline 6 & ES & 62 \\
\hline 7 & AM & 75 \\
\hline 8 & MO & 82 \\
\hline 9 & RP & 65 \\
\hline 10 & MF & 50 \\
\hline 11 & DF & 46 \\
\hline
\end{tabular}




\begin{tabular}{lll}
\hline 12 & RM & 60 \\
\hline 13 & RS & 57 \\
\hline 14 & RF & 71 \\
\hline 15 & DA & 81 \\
\hline 16 & NA & 40 \\
\hline 17 & FN & 53 \\
\hline 18 & MV & 83 \\
\hline 19 & MA & 55 \\
\hline 20 & DF & 75
\end{tabular}

Source : Japanese Language Study Program Data 2019

Table 3

List of Final Exam Score of General Korean Language

Even Semester Academic Year 2018/2019 Class of 2018 Korean Language Study Program SV UGM

\begin{tabular}{|c|c|c|}
\hline No & Respondent & Final Score \\
\hline 1 & $\mathrm{HN}$ & 42 \\
\hline 2 & YS & 81 \\
\hline 3 & SA & 68 \\
\hline 4 & NPD & 89 \\
\hline 5 & NP & 68 \\
\hline 6 & $\mathrm{RS}$ & 96 \\
\hline 7 & NAF & 80 \\
\hline 8 & $\mathrm{AL}$ & 36 \\
\hline 9 & $\mathrm{NO}$ & 86 \\
\hline 10 & DAA & 57 \\
\hline 11 & IA & 70 \\
\hline 12 & SA & 71 \\
\hline 13 & $\mathrm{AE}$ & 86 \\
\hline 14 & APA & 42 \\
\hline 15 & WD & 45 \\
\hline 16 & ASF & 96 \\
\hline 17 & KS & 64 \\
\hline 18 & $\mathrm{ZS}$ & 59 \\
\hline 19 & AMA & 74 \\
\hline 20 & $\mathrm{ACN}$ & 71 \\
\hline 21 & SP & 79 \\
\hline 22 & $\mathrm{LF}$ & 69 \\
\hline 23 & $\mathrm{KL}$ & 84 \\
\hline 24 & MR & 77 \\
\hline 25 & SAS & 37 \\
\hline 26 & $\mathrm{YF}$ & 86 \\
\hline
\end{tabular}

Source: Korean Language Study Program Data 2019 
The final score average for the Japanese language study program is 65.2 and for Korean language study program is 69.7. Although it is over 50, this score distribution in the classes which includes vocabularies, still cannot be used as the benchmark that student's learning style has supported their studying achievement.

\subsection{Students Learning Style and Vocabulary Learning}

Learning style is considered the easiest way for a learner to absorb, process, and manage information received. A suitable learning style certainly will make students satisfied with the result achieved showed by their score. Studying result is the ability owned by student after they receive their studying experience [8].

There are three types of learning style; they are visual, auditory, and kinesthetic [9]. This research is using sensory preferences; they are visual, auditory, and kinesthetic learning styles. The reason for using sensory preference is because, in the process, the learning style of the students could be observed by a sense organ. Based on the sensory preference, visual learner learn through the thing that they see, the auditory learner learns through hearing, and kinesthetic learner learns through the motion, work, and touch. Each student has those three learning styles, but only one style is more dominant than the others. From these questionnaires, it could be seen the learning style of students in two study programs.

Table 4

Learning Style of Diploma 3 Japanese Language Study Program

\begin{tabular}{lcc}
\hline \multicolumn{1}{c}{ Learning Style } & $\begin{array}{c}\text { Number } \\
\text { of } \\
\text { Students }\end{array}$ & Percentage \\
\hline Visual & 6 & 30 \\
\hline Visual-Auditory-Kinesthetic & 4 & 20 \\
\hline Visual- Kinesthetic & 3 & 15 \\
\hline Auditori- Kinesthetic & 1 & 5 \\
\hline Visual-Auditory & 1 & 5 \\
\hline Not Decided & 5 & 25 \\
\hline \multicolumn{1}{c}{ Total } & $\mathbf{2 0}$ & $\mathbf{1 0 0 \%}$ \\
\hline
\end{tabular}

Table 5

Learning Style of Diploma 3 Korean Language Study Program

\begin{tabular}{lcc}
\hline \multicolumn{1}{c}{ Learning Style } & $\begin{array}{c}\text { Number } \\
\text { of } \\
\text { Students }\end{array}$ & Percentage \\
\hline Visual & 3 & 12 \\
\hline Auditory & 5 & 19 \\
\hline Kinesthetic & 4 & 15 \\
\hline Auditory- Kinesthetic & 3 & 12 \\
\hline Visual-Auditory- Kinesthetic & 1 & 4 \\
\hline
\end{tabular}




\begin{tabular}{lcc}
\hline Not Decided & 10 & 38 \\
\hline Total & $\mathbf{2 6}$ & $\mathbf{1 0 0 \%}$ \\
\hline
\end{tabular}

Source: Research Data 2019

From the questionnaire result, it could be seen that students of the Japanese Language study program tend to study in visual style, although there are still variations of mixing between visual auditory, visual kinesthetic, and the combination of those three. Students in the Korean Language Study Program, as seen from the table, mostly (10 students) still cannot decide their learning style. For those choosing the learning style, most of them (5 students) choose the auditory learning style

To know the effectiveness of students' learning style with their studying result, besides the final score shown in table 2 and table 3 , it should be linked to the vocabulary learning which has been done by the students themselves. Here is the questionnaire whose questions related to their vocabulary learning style. Based on the questionnaire result, there is data with the interval of answer frequency shown below.

Table 6

\begin{tabular}{ll}
\hline $0-24.99 \%$ & Never \\
\hline $25-49.99 \%$ & Seldom \\
\hline $50-74.99 \%$ & Often \\
\hline $75-100$ & Always \\
\hline
\end{tabular}

Table 7

Questionnaire Result of Japanese Language Study Program Class of 2018 Vocabularies Learning

\begin{tabular}{lllccccc}
\hline No & Vocabulary Learning & Always & Often & Seldom & Never & \% & $\begin{array}{c}\text { Catego } \\
\text { ry }\end{array}$ \\
\hline 1 & $\begin{array}{l}\text { Take note of new vocabularies } \\
\text { received in class }\end{array}$ & 9 & 9 & 2 & 0 & $78.33 \%$ & Always \\
\hline 2 & $\begin{array}{l}\text { Re-read vocabularies note that had } \\
\text { been learned at home }\end{array}$ & 2 & 11 & 7 & 0 & $58.33 \%$ & Often \\
\hline 3 & $\begin{array}{l}\text { Take note the vocabularies of the } \\
\text { materials although they are already } \\
\text { written in the book }\end{array}$ & 4 & 10 & 6 & 0 & $63.33 \%$ & Often \\
\hline 4 & $\begin{array}{l}\text { It is enough to read briefly learned } \\
\text { vocabularies (in the book) }\end{array}$ & 0 & 6 & 10 & 4 & $36.67 \%$ & Seldom \\
\hline 5 & $\begin{array}{l}\text { Score related to vocabularies is } \\
\text { satisfactory }\end{array}$ & 0 & 13 & 7 & 0 & $55.00 \%$ & Often \\
\hline 6 & $\begin{array}{l}\text { It is hard to memorize new } \\
\text { vocabularies }\end{array}$ & 10 & 7 & 1 & $55.00 \%$ & Often \\
\hline 7 & $\begin{array}{l}\text { It is hard to remember } \\
\text { vocabularies because it has no } \\
\text { picture in the book }\end{array}$ & 8 & 6 & 4 & $46.67 \%$ & Seldom \\
\hline
\end{tabular}




\begin{tabular}{llllllll}
\hline 8 & $\begin{array}{l}\text { It is hard to construct a sentence in } \\
\text { a foreign language }\end{array}$ & 15 & 11 & 4 & 0 & $68.33 \%$ & Often \\
\hline 9 & $\begin{array}{l}\text { It is hard to build a sentence due to } \\
\text { the limit of vocabularies mastered }\end{array}$ & 5 & 12 & 3 & 0 & $70.00 \%$ & Often \\
\hline
\end{tabular}

Table 8

Questionnaire Result of Korean Language Study Program Class of 2018 Vocabularies Learning

\begin{tabular}{llcccccc}
\hline No & Vocabulary Learning & Always & Often & Seldom & Never & \% & Category \\
\hline 1 & $\begin{array}{l}\text { Take note of new vocabularies } \\
\text { received in class }\end{array}$ & 14 & 11 & 1 & 0 & $81.33 \%$ & Always \\
\hline 2 & $\begin{array}{l}\text { Re-read vocabularies note that had } \\
\text { been learned at home }\end{array}$ & 3 & 17 & 5 & 1 & $61.34 \%$ & Often \\
\hline 3 & $\begin{array}{l}\text { Take note the vocabularies of the } \\
\text { materials although they are already } \\
\text { written in the book }\end{array}$ & 6 & 13 & 4 & 3 & 61.54 & Often \\
\hline 4 & $\begin{array}{l}\text { It is enough to read briefly learned } \\
\text { vocabularies (in the book) }\end{array}$ & 0 & 6 & 14 & 6 & $33.33 \%$ & Seldom \\
\hline 5 & $\begin{array}{l}\text { Score related to vocabularies is } \\
\text { satisfactory }\end{array}$ & 0 & 10 & 15 & 1 & $44.87 \%$ & Seldom \\
\hline 6 & $\begin{array}{l}\text { It is hard to memorize new } \\
\text { vocabularies }\end{array}$ & 5 & 11 & 9 & 1 & $58.97 \%$ & Often \\
\hline 7 & $\begin{array}{l}\text { It is hard to memorize vocabularies } \\
\text { because it has no picture in the } \\
\text { book }\end{array}$ & 3 & 6 & 10 & 7 & $33.74 \%$ & Seldom \\
\hline 8 & $\begin{array}{l}\text { It is hard to construct a sentence in } \\
\text { a foreign language }\end{array}$ & 4 & 14 & 7 & 1 & $60.26 \%$ & Often \\
\hline 9 & $\begin{array}{l}\text { It is hard to construct a sentence } \\
\text { due to the limit of vocabularies } \\
\text { mastered }\end{array}$ & 10 & 11 & 5 & 0 & $73.08 \%$ & Often \\
\hline
\end{tabular}

\section{Sources: Research Data 2019}

Respondents of this research are $\mathrm{Z}$ generation, the characteristics of $\mathrm{Z}$ generation as stated by [4] are: like audiovisual format, depending on technology, easy to understand real example, critical when delivering an idea, learn better from the teacher who acts as a friend, and likes to innovate. From the table above, it can be seen that the percentage of students who take note of the vocabulary learned in the class is in the high interval. Students with the visual learning style usually like to take notes, and the notes are supporting the score that they hope. Although it is said that $\mathrm{Z}$ generation likes audiovisual format, from the data above, respondents do not put the importance of pictures in learning vocabularies. This can be an indication that the obstacle of vocabulary learning in both study programs is not because of the lack of images in the teaching materials.

Those who answer 'taking note and re-read the note' to support the understanding are more than $50 \%$, but those who said that it is hard to memorize vocabularies are also in high percentage. Besides that, the percentage of students satisfied with their score is $55 \%$ for the Japanese language and $44 \%$ for the Korean Language. The majority of answer frequency is in 
interval 2, which shows that the satisfactory level of the students to their studying result is not maximum. The respondents also confess that one of the biggest problems to master a foreign language is the lack of vocabulary ( more than $60 \%$ answer that it is hard to construct a sentence because they lack vocabulary).

$\mathrm{Z}$ generation is known to love innovation and close to the internet. A survey done by APJII (Association of Internet Service Providers in Indonesia) in 2017 shows that internet penetration to $\mathrm{Z}$ generation reaches $75.5 \%$ higher than the previous generation. Referring to the research done by www.tirto.id in June 2017, the average of $\mathrm{Z}$ generation access 3-5 hours of internet per day $(34 \%)$ and $7.3 \%$ of them access the internet more than 12 hours a day[10]. This data shows the assumption that $\mathrm{Z}$ generation, the students of Japanese and Korean Language Study Program in SV UGM spend most of their time to access the internet. However, it is still not used to the activity of Japanese or Korean language vocabulary learning.

Aside from that, the observation by the researcher to the students of both study program on the passing of language proficiency test has become the benchmark to the Japanese language skill. It is Japan Language Proficiency Test (JLPT) and Test of Proficiency in Korean (TOPIK) for the Korean Language still not showing maximum result. For the Japanese Language Study Program, most respondents have taken JLPT, the percentage of students passing is 30\%. Meanwhile, in Korean Language Study Program, from 26 respondents, those who took the test and passed is in the percentage of 27\% (Data from Japanese and Korean language study program SV UGM, 2018). The data shows the need for motivation for the students to keep improving the vocabulary learning for Japanese and Korean Language to be fluent in communication both in theory and in practice.

What is meant by learning style is the easiest way owned by the individual in absorbing, managing, and processing the information received [11]. Moreover, according to Chania Y [8] learning style is an action that is felt interesting by the student in doing learning activity, either when alone or in a study group together with their school friends [8]. From the discussion above, it can be seen that students' learning style is not yet optimal shown by the dissatisfaction of score achieved and also the level of difficulties experienced. Students as $\mathrm{Z}$ generation are not yet optimizing gadgets to learn vocabularies and are not innovating their learning styles.

Learning is the effort seeking for meaning. The purpose of learning is individually to construct meaning that they hope, not only to remember the correct answer to a question. Each individual has a unique learning style, depends on the age, habit, social environment, including educational institution, motivation, and the purpose of learning. These various styles of learning have a characteristic which then called a learning strategy (Harsono, without year).

If the learning strategy is an information processing pattern used for memory test/exam, so what it means by learning style is a predisposition from a group of students to adopt a specific learning strategy without thinking about particular demand from learning purposes. The teacher can influence students' learning strategies, but learning style is not like that. Students have applied learning strategy given by the lecturer in the questionnaire, which is taking note and re-read the note, but from the questionnaire itself, it is seen that this strategy is not enough to affect their learning style. Learning style must emerge from the individual who has a willingness to study, and not only for the sake of score. Hence, the role of a teacher is to find the new strategy to inspire $\mathrm{Z}$ generation in utilizing their closeness to technology to be part of their learning style. 


\section{CONCLUSION}

Vocabulary mastery is important to each foreign language learning, no exception is for Japanese and Korean Language learning in Vocational College, UGM. in both of these study programs, each curriculum has been applied to infuse the importance of vocabulary learning to the students. However, all of them depend on each individual with their learning style. Learning style is a way for an individual to absorb information received, require the students to have motivation for the finding of the suitable learning style of Japanese and Korean Language's vocabulary learning.

Research result shows that student's learning style which is part of $\mathrm{Z}$ generation is not yet significantly satisfactory in score achievement and its implication on the recognized international test result of Japanese and Korean Language proficiency tests (JLPT and TOPIK). Students are not fully optimizing their closeness to gadgets for vocabulary learning. That is why the role of teacher to give motivation to the students to understand their learning style based on their motivation to learn Japanese and Korean language, includes the participation of gadget in the learning process of $\mathrm{Z}$ generation.

For the next research, it will be executed the experiment using kahoot.it for Japanese and Korean language vocabulary learning. Kahoot.it needs a gadget for the operation and hopefully, it can push ahead of the spirit of students from $\mathrm{Z}$ generation to explore the digital world more deeply so in the future they can find the most suitable learning style for their generation.

\section{REFERENCE}

[1] The Japan Foundation, "Survey Report on Japanese Language Education Abroad," Tokyo, 2015.

[2] Strait Times, "Korsel-Indonesia Sepakat Kerjasama Ekonomi dan Pertukaran Masyarakat," 2018. [Online]. Available: https://www.matamatapolitik.com/koreaselatan-indonesia-sepakat-tingkatkan-kerjasama-ekonomi-dan-pertukaran-masyarakat. [Accessed: 27-Nov-2019].

[3] Pratama. H. C., Cyber Smart Parenting. Bandung: PT. Visi Anugerah Indonesia, 2012.

[4] Majalah 1000 guru, "Menyelami Gaya Belajar Ala Generasi Z | Majalah 1000guru," 2016. [Online]. Available: http://majalah1000guru.net/2016/08/gaya-belajar-generasiz/. [Accessed: 04-Dec-2019].

[5] S. N. Tjandra, Sintaksis Jepang. Jakarta: BINUS Media \& Publishing, 2013.

[6] TOPIK, "About the Test | TOPIK Test of Proficiency in Korea," 2014. [Online]. Available: http://www.topik.go.kr/usr/cmm/subLocation.do?menuSeq=2210101\#none. [Accessed: 04-Dec-2019].

[7] M. Alqahtani, "The importance of vocabulary in language learning and how to be taught," Int. J. Teach. Educ., vol. III, no. 3, pp. 21-34, 2015.

[8] Y. Chania, M. Haviz, D. Sasmita, J. Sudirman, N. Kubu, and R. Limokaum, "HUBUNGAN GAYA BELAJAR DENGAN HASIL BELAJAR SISWA PADA PEMBELAJARAN BIOLOGI KELAS X SMAN 2 SUNGAI TARAB KABUPATEN TANAH DATAR," vol. 8, no. 1, pp. 77-84, 2016.

[9] B. DePorter and M. Hernacki, Quantum Learning, Revisi. Bandung: Kaifa, 2000.

[10] A. Saepurrohman and Y. Paranoan, "Pola Pendidikan yang Tepat Bagi Generasi Z dan Generasi Alfa - Direktorat Guru \& Tenaga Kependidikan Madrasah,” 2019. [Online]. Available: https://gtkmadrasah.kemenag.go.id/2019/07/03/pola-pendidikan-yang- 
tepat-bagi-generasi-z-dan-generasi-alfa/. [Accessed: 27-Nov-2019].

[11] J. B. Arylien Ludji Bire, Uda Geradus, "Pengaruh Gaya Belajar Visual, Auditorial, Dan Kinestetik Terhadap Prestasi Belajar Siswa," J. Kependidikan Peneltian Inov. Pembelajaran, vol. 44, no. 2, pp. 168-174, 2014. 